\title{
Detection of Causal Relationship among Apricot Production, Dollar Exchange Rate and Gold Prices Using Co-integration Analysis and VECM: The Case of Turkey
}

\author{
Senol Celik \\ Bingol University, Agricultural Faculty Animal Science Department, Bingol, Turkey
}

\begin{abstract}
In this study, causalities among apricot production (AP), dollar exchange rate (DE) and gold price (GP) are examined for Turkey using data covering the period from 1950 to 2015. The co-integration analysis and vector error correction model (VECM) are used the casualty relationship among $A P, D E$, and GP in predicting. According to unit root test, results indicate that each of series is not stationary, when the variables are defined in levels; but that each of series is stationary, when the variables are defined in first differences. Johansen's co-integration test results show that there exists a long-run equilibrium relationship among AP, DE, and GP. It is concluded that there is one co-integration vector in the data. Since the series are found to be co-integrated, it used VECM model to test the existence of causality. According to the VECM, there has been long-term relationship among the variables.
\end{abstract}

Keywords: Stationary, long-run changes, apricot production

\section{Introduction}

Apricot production is very important for Turkey. According to FAO data (2013a), Turkey ranks first in amount of apricot production among the world's countries. Then from Turkey, Iran ranks second with 457308 tons, Uzbekistan is the third with 430000 million tons, Algeria is the fourth with 319784 and Italy is the fifth with 198290 tons of apricot production in the world.

According to Turkish Statistical Institute (TSI), in Turkey, amount of apricot production has reached the highest amount of 894000 tons in 2005. Amount of apricot production has amounted to 811609 tons in 2013, 278210 tons in 2014 and 696100 tons in 2015 (TSI, 2013; TSI, 2015).

In terms of exports of dried apricots, Turkey is ranked first with export value of 314134000 dollars in the world. Exports of dried apricots values are total of 405386000 dollar in the world (FAO, 2013b). Turkey apricot export value constitutes $77.49 \%$ of the world's total apricot export value. Briefly, Turkey is ranked first both in the production of apricots and export of apricots in the world. In this case, apricot production is extremely important in terms of Turkey's economy.

In a study on 26 developed and developing countries where they run a panel co-integration analysis conclude that the Fisher Hypothesis is valid by determined Berument and Jelassi (2002). The Fisher Hypothesis for Britain based on the co-integration analysis, concluding that there is a long term relationship between inflation rate and interest rates by tested Granville and Mallick (2004). Barriors et al (2005) confirmed on their study of Irish companies that, at first, negative competition effect is stronger, but with the accumulation of FDI (Foreign Direct Investment) positive effects dominate the initial negative effects.
The purpose of this study is to examine the long-term relations among amount of apricot production (AP), dollar exchange rate (DE) and gold price (GP) using Johansen cointegration method VECM in Turkey.

\section{Material and Method}

In this work, all data examined in this research apricot production, dollar exchange rate and price of gold are collected from the TSI Statistics. The agricultural data on the amount of apricot production and gold price from the period 1950 to 2013 evaluated in the study were supplied from Statistical Indicators" book published by TSI 2014. The amount of apricot production (2014 and 2015 years) data are taken from TSI's web site (http://www.tuik.gov.tr/PreTablo.do?alt_id=1001). Dollar exchange rate values published by the Republic of Turkey Central Bank (CBT) have been used (CBT, 2016). The data is annual the time period 1950 to 2015 . All variables are expressed in logarithm.

Generally, most economic variables are non-stationary. Nonstationary or integration properties of the time series are examined using the widely used augmented Dickey-Fuller (ADF) (Dickey and Fuller, 1976) and Phillips-Perron (PP) (Phillips and Perron, 1988) unit root tests. Long-term relationships are determined by co-integration analysis. Cointegration test (Equation 1)

$$
\lambda_{\text {Trace }}(r)=-T \sum_{i=r+1}^{p} \ln \left(11-\widehat{\lambda}_{i}\right)
$$

is shaped (Enders, 2010). Here, T: Number of observation, $\lambda$ : Eigen values.

Granger and Newbold (1974) noted that the regression results from the VECM models of the Granger causality 


\section{International Journal of Science and Research (IJSR) \\ ISSN (Online): 2319-7064 \\ Index Copernicus Value (2013): 6.14 | Impact Factor (2015): 6.391}

tests using non-stationary variables will be spurious. To avoid this, we will run the regression with the stationary variables after differencing. According to Hsing (2009) modified error correction model is given in Equation 2.

$$
\begin{aligned}
& \Delta \log A P=\alpha+\sum_{i=0}^{p} \theta(i) \Delta \log A P \\
&+\sum_{i=0}^{p} \beta(i) \Delta \log D E \\
&+\sum_{i=0}^{p} \gamma(i) \Delta \log G P+\varphi E C T_{t-1}+\varepsilon_{t}
\end{aligned}
$$

\section{Results}

Co-integration analysis has been used to determine the relationship between apricot production, dollar exchange rate and gold price causality analysis using vector error correction to determine the short-term relationships. To make this analysis, primarily the variables are determined to be static or not with the unit root test. If the variables are not stable, but stable on their first difference, the long-run equilibrium relationship is determined. If there is a cointegration relationship among the variables, short-term and long-term causality results are interpreted estimating VECM.

In order to determine whether the series does or does not contain unit roots, ADF unit root and Phillips Perron (P-P) tests have been carried out. The results of the ADF unit root and Phillips Perron test of the variables used in the study are showed in Table 1 . When Table 1 is examined, it is understood that zero hypothesis related to unit root is accepted in AP dollar exchange rate (DE) and gold price (GP) variables and that the variables at the level values are not stable. As shown in Table 1, the variables are free from unit root in the first differences and they are stable. Thus $\mathrm{AP}, \mathrm{DE}$, and GP variables are determined to be static $I(1)$ in the first differences $(P<0.01)$.

Table 1: Unit Root Test

\begin{tabular}{|c|c|c|c|c|}
\hline & \multicolumn{2}{|c|}{ ADF test statistics } & \multicolumn{2}{c|}{ Phillips Perron test statistics } \\
\hline Variables & Level & First difference & Level & First difference \\
\hline Apricot Production $(\log (\mathrm{AP}))$ & -1.320 & $-11.74^{* * *}$ & -1.696 & $-31.630^{* * *}$ \\
\hline Dollar exchange rate $\log ((\mathrm{DE}))$ & -0.058 & $-5.223 * * *$ & 0.378 & $-5.444^{* * *}$ \\
\hline Gold price $\log ((\mathrm{GP}))$ & -1.262 & $-4.862 * * *$ & -1.439 & $-4.897^{* * *}$ \\
\hline The level of significance & Critical values & Critical values & Critical values & Critical values \\
\hline $1 \%$ & -3.538 & -3.537 & -3.534 & -3.538 \\
\hline $5 \%$ & -2.908 & -2.908 & -2.907 & -2.908 \\
\hline $10 \%$ & -2.592 & -2.591 & -2.591 & -2.592 \\
\hline
\end{tabular}

For specify the optimal $\operatorname{lag}(k), \log L$ statistics - $\log L, \mathrm{LR}-$ sequential modified LR test statistic (each test at $5 \%$ level), FPE-final prediction error, AIC-Akaike information criterion, SC-Schwarz information criterion, LM-
Lagrange multiplier, and HQ-Hannan-Quinn information criterion values are given in Table 2 . When Table 2 is determined, it is seen that the model with the lag number 2 " according to LR, FPE, and AIC values should be selected.

Table 2: Statistics for selecting the lag order of the equation

\begin{tabular}{|c|c|c|c|c|c|c|}
\hline Lag & LogL & LR & FPE & AIC & SC & HQ \\
\hline 0 & -282.4409 & NA & 2.721205 & 9.514697 & 9.619414 & 9.555657 \\
\hline 1 & -8.307563 & 511.7156 & 0.000395 & 0.676919 & $1.095788 *$ & $0.840761 *$ \\
\hline 2 & 1.785245 & $17.83063 *$ & $0.000382 *$ & $0.640492 *$ & 1.373512 & 0.927216 \\
\hline 3 & 8.783587 & 11.66390 & 0.000411 & 0.707214 & 1.754386 & 1.116820 \\
\hline 4 & 15.77765 & 10.95736 & 0.000444 & 0.774078 & 2.135402 & 1.306567 \\
\hline 5 & 21.32427 & 8.135041 & 0.000508 & 0.889191 & 2.564667 & 1.544562 \\
\hline 6 & 24.43672 & 4.253688 & 0.000636 & 1.085443 & 3.075070 & 1.863695 \\
\hline
\end{tabular}

* indicates lag order selected by the criterion

LR: sequential modified LR test statistic (each test at 5\% level), FPE: Final prediction error, AIC: Akaike information criterion, SC: Schwarz information criterion, HQ: HannanQuinn information criterion.

Since AP, DE, and GP variables are stable in the first differences, the existence of a long-term relationship among these variables is examined via co-integration test, according to Johansen method (1988) and Johansen-Juselius method (Johansen and Jeselius, 1990). The obtained results are presented in Tables 3. In Tables 3, it is shown that at least 1 co-integrated vector is found in co-integration tests conducted to identify the numbers of co-integrated vectors.
When Table 3 is examined, it is seen that while $\lambda_{\mathrm{i}}$ is showing self- values, the hypothesis $\mathrm{H}_{0}\left(\mathrm{H}_{0}: r=0\right)$ showing that no co-integrated vector is available is tested against the hypothesis $\mathrm{H}_{1}$ arguing that at least 1 co-integrated vector is available. As a result, it is found out that 1 co-integrated vector are available $(P<0.05)$.

Table 3: Co-integration Trace Test Results

\begin{tabular}{|c|c|c|c|c|}
\hline Hypothesized & & Trace & 0.05 & \\
\hline No. of CE(s) & Eigenvalue & Statistic & Critical Value & Prob. $^{*}$ \\
\hline None $^{*}$ & 0.272885 & 34.81113 & 29.79707 & 0.0122 \\
\hline At most 1 & 0.190537 & 14.73490 & 15.49471 & 0.0649 \\
\hline At most 2 & 0.022252 & 1.417735 & 3.841466 & 0.2338 \\
\hline
\end{tabular}

\section{Volume 5 Issue 7, July 2016 www.ijsr.net}




\section{International Journal of Science and Research (IJSR) \\ ISSN (Online): 2319-7064 \\ Index Copernicus Value (2013): 6.14 | Impact Factor (2015): 6.391}

Trace test indicates 1 co-integrating eqn(s) at the 0.05 level, * denotes rejection of the hypothesis at the 0.05 level, **MacKinnon-Haug-Michelis (1999) p-values.

Trace statistics value calculated as $34.811,29.797$ is greater than the critical value of $29.797 \mathrm{H}_{0}$ hypotheses is rejected $(P<0.05)$. Therefore, co-integrating vectors observed in the model. According to the co-integration test results, there is a long-term relationship among AP, DE, and GP. According to the results obtained for $p=2$ according to $\lambda_{\text {trace }}$ statistics, the rank number has been obtained as $1(P<0.05)$.

As the results given in Table 4, the apricot production amount, and price of gold values have affected themselves negatively after a period of delay first and second (respectively $-0.295,-0.261,-0.225$ and -0.191 ). Dollar exchange rate values have effected themselves positively after a period of delay first and second (respectively 0.218 and 0.076). When the apricot production amount is the dependent, variables dollar exchange rate and price of gold impact are statistically insignificant. Moreover, 1-unit increase in the dollar exchange rate bring about a unit of 0.218 and 0.076 respectively increase in apricot production amount. 1-unit increase in the price of gold values bring about a unit of 0.225 and 0.191 respectively decrease in apricot production amount. Since the impact of this decrease is insignificant, a short-term causality from price of gold towards apricot production amount cannot be identified. Besides, because of the dollar exchange rate increase is insignificant, a short-term causality from dollar exchange rate towards apricot production amount cannot be identified.

The error correction term $\left(E C T_{t-1}\right)$ coefficient has been found as -0.726 and as statistically significant. In this case, long-term causality from dollar exchange rate and price of gold towards apricot production amount is identified (Equation 2). Lagged error correction terms $\left(E C T_{t-1}\right)$ show that deviation among apricot production amount, dollar exchange rate and price of gold values and long-term values appear up to $72.6 \%$ each year. According to the statistical tests of the models, the model determination coefficients $\left(R^{2}\right)$ are determined to be 0.565 . By $F$ test, model as a whole is found significant $(P<0.01)$. As the result of DW is 2.008 statistical values, the models do not show any autocorrelation.

Table 4: VECM Models Results

\begin{tabular}{|c|c|c|c|}
\hline $\begin{array}{c}\text { Dependent } \\
\text { variable: AP }\end{array}$ & Coefficient & t-Statistic & Prob. \\
\hline Constant & 0.148742 & 1.843707 & 0.0706 \\
\hline $\mathrm{AP}_{\mathrm{t}-1}$ & -0.294633 & -1.596096 & 0.1162 \\
\hline $\mathrm{AP}_{\mathrm{t}-2}$ & -0.261381 & -1.938482 & 0.0577 \\
\hline $\mathrm{DE}_{\mathrm{t}-1}$ & 0.218046 & 1.192699 & 0.2381 \\
\hline $\mathrm{DE}_{\mathrm{t}-2}$ & 0.076267 & 0.432014 & 0.6674 \\
\hline $\mathrm{GP}_{\mathrm{t}-1}$ & -0.224574 & -1.135035 & 0.2613 \\
\hline $\mathrm{GP}_{\mathrm{t}-2}$ & -0.190688 & -0.897103 & 0.3736 \\
\hline $\mathrm{ECT}_{\mathrm{t}-1}$ & -0.726394 & -3.350175 & 0.0015 \\
\hline $\mathrm{R}-\mathrm{squared}$ & 0.565021 & & \\
\hline F-statistic & 10.20611 & & 0.000000 \\
\hline Durbin-Watson statistics & 2.0081 & & \\
\hline
\end{tabular}

The sum of recursive residuals (CUSUM) test is applied to assess the parameter stability. Figure 1 the results for CUSUM tests. Since the plot of the CUSUM statistic fall inside the critical values of the $5 \%$ confidence interval of parameter stability, the absence of any instability of the coefficients

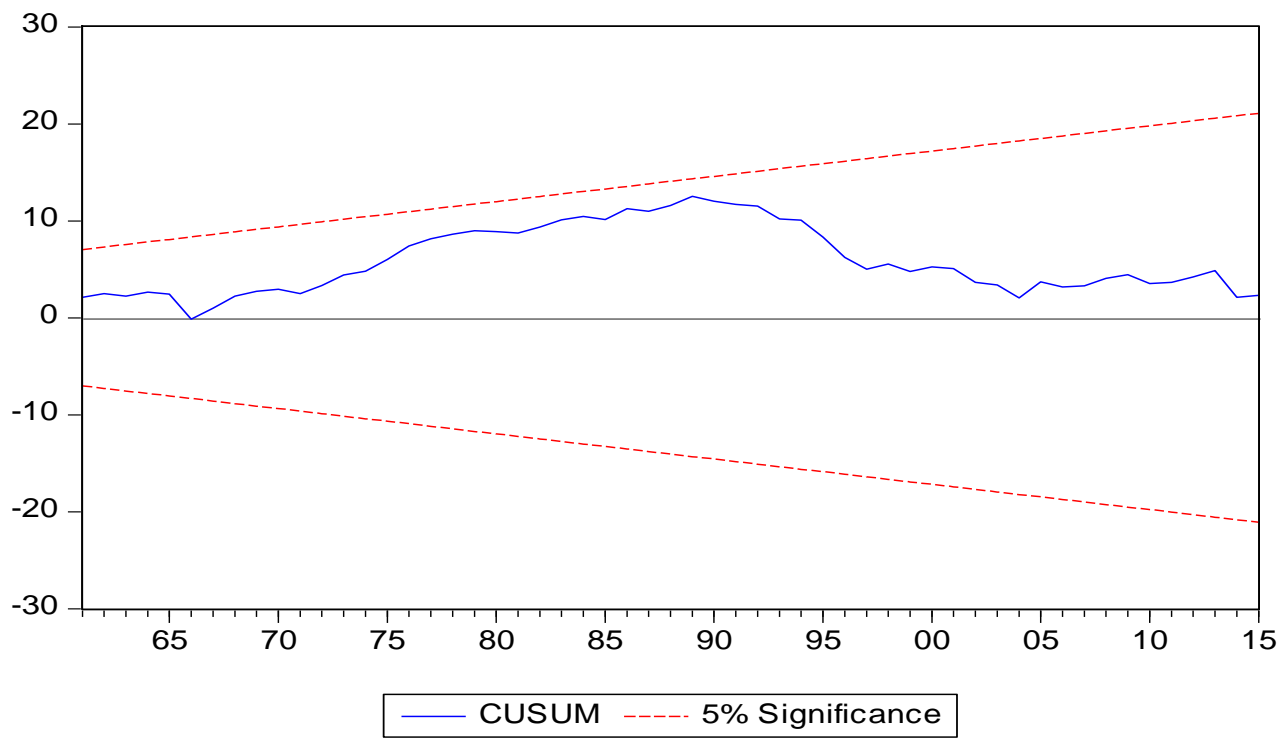

Figure 1: Plot of CUSUM Test

\section{Conclusions}

This research contributes to making understood cointegrating and causal relationship among AP, DE, and GP in Turkey. To develop this research, the Johansen approach to co-integration test was used. VECM model was used in order to test for the presence of a long-run relationship among these variables.

Amount of apricot production, dollar exchange rate, and price of gold variables are found to be co-integrated in Turkey in the period from 1950 to 2015. A positive 


\section{International Journal of Science and Research (IJSR) \\ ISSN (Online): 2319-7064}

Index Copernicus Value (2013): 6.14 | Impact Factor (2015): 6.391

relationship is found between the amount of apricot production and dollar exchange rate and a positive relationship between amount of apricot production and price of gold, when a single co-integrated vector is taken.

According to a VECM results, short-term causal relationship is not found from dollar exchange rate to amount of apricot production. Also, short-term causal relationship is not found from price of gold to amount of apricot production. But, long-term causal relationship is found from dollar exchange rate to amount of apricot production and long-term causal relationship is found from price of gold to amount of apricot production.

\section{References}

[1] Barriors, S., Gorg, H., Stobl, E. 2005. Foreign direct investment, competition and industrial development in the host country. European Economic Review 49(8): 1761-1784

[2] Berument, H., Jelassi, M. M. 2002. The Fisher Hypothesis: A Multi-Country Analysis. Applied Economics 34: 1645-1655.

[3] CBT, 2016. Republic of Turkey Central Bank. The indicative exchange rate of the central bank. http://www.tcmb.gov.tr/wps/wcm/connect/tcmb+tr/tcm $\mathrm{b}+\mathrm{tr} / \mathrm{main}+\mathrm{menu} /$

istatistikler/doviz+kurlari/alim+satim (Accessed to: 04.06.2016).

[4] Enders, W. 2010. Applied Econometrics Time Series. John Wiley and Sons, Inc.

[5] FAO, 2013a. Food and Agriculture Organization. Crops Production Statistics. http://faostat3.fao.org/download/Q/QC/E (Accessed to: 23.07.2016).

[6] FAO, 2013b. Food and Agriculture Organization. Trade of Crops and Livestock Products. http://faostat3.fao.org/download/T/TP/E (Accessed to: 23.07.2016).

[7] Granger, C. W. J., Newbold, P. 1974. Spurious Regression in Econometrics. Journal of Econometrics 2: 111-120.

[8] Granville M., Mallick S. 2004. Fisher Hypothesis: UK evidence over a century. Applied Economic Letters, 11: 87-90.

[9] Johansen, S. 1988. Statistical Analysis of Cointegration Vector. Journal of Economics Dynamic and Control, 12:231-254.

[10] Johansen, S., Juselsus, K. 1990. Maximum Likelihood Estimation and Inference on Co- integration with Application to The Demand For Money. Oxford Bulletin of Economics and Statistics, 52: 169-210.

[11] Hsing, Y. 2009. Responses of Output to Declining Stock Values and Real Depreciation in Lithuania. International Economics, 62: 429-437.

[12] Phillips, P. / Peron, P. 1988. Testing for a Unit Root in Time Series Regression. Biometrica, 75: 335-345.

[13] TSI, 2013. Turkish Statistical Institute. Statistical Indicators Turkey Statistical Institute Publications, Publication Number: 4361, Ankara.

[14] TSI, 2015. Turkish Statistical Institute. Crop Production Statistics. http://www.tuik.gov.tr/PreTablo.do?alt id=1001(Acce ssed to: 18.07.2016). 